\title{
Protoparmelia capitata (Ascomycota: Parmeliaceae): new record for South America
}

André Aptroot ${ }^{1}$, Maria Machado de Oliveira ${ }^{2}$ and Marcela Eugenia da Silva Cáceres ${ }^{2,3}$

Received: 10 January, 2013. Accepted: 5 July, 2013

\begin{abstract}
The sterile corticolous crustose lichen Protoparmelia capitata (Ascomycota: Parmeliaceae), recently described for southeastern North America, is reported as a new record for South America in the Serra da Jiboia mountain range, near the municipality of Santa Teresinha, in the state of Bahia, in northeastern Brazil. This species is locally common and is probably closely related to $P$. isidiata, which has the same pigmentation and medullary chemistry, $P$. capitata differing from $P$. isidiata in that the former features soredia rather than isidia.
\end{abstract}

Key words: Alectoronic acid, sorediate species, new record, Serra da Jiboia, Santa Teresinha, Bahia, northeastern Brazil, caatinga, Atlantic Forest

\section{Introduction}

Protoparmelia is the main crustose genus in the family Parmeliaceae, which encompasses numerous foliose and fruticose genera and species. The name of the genus suggests that it is the ancestor of the family, and phylogenetically it is indeed a sister clade to the remainder of the genera now classified in the Parmeliaceae (Arup et al. 2007; Papong et al. 2011). It has the characteristic cupular exciple, a synapomorphic character common to all Parmeliaceae (Henssen 1995), and a character absent from a similar family, Lecanoraceae. Many Protoparmelia species share a unique character that is often overlooked: the presence of multiple cilia on the exterior surfaces of their ascospores (Brodo \& Aptroot 2005). In addition, Protoparmelia species closely resemble Lecanora (the type genus of Lecanoraceae), except that all Protoparmelia species have a brown pigment in the cortex, much as in another Parmeliaceae genus, Neofuscelia.

With the recent inclusion of the polysporous species that were formerly classified in the genus Maronina (Papong et al. 2011), the genus Protoparmelia now comprises approximately 30 species (Kalb 1984; Poelt \& Leuckert 1991; Poelt \& Grube 1992; Ryan et al. 2004; Aptroot et al. 1997; Brodo \& Aptroot 2005; Cáceres 2007; Boom et al. 2007; Elix 2007; Lendemer \& Lumbsch 2008; Papong et al. 2011) and occurs all over the world. Although most Protoparmelia species are saxicolous, a few are corticolous. In the tropics, one species, P. isidiata Diederich, Aptroot
\& Sérus., is widespread and often locally common. It was described for Papua New Guinea (Aptroot et al. 1997) where it occurs with the related P. pulchra Diederich, Aptroot \& Sérus., with which it clearly forms a species pair. Protoparmelia isidiata was subsequently reported for Brazil (Aptroot 2002), Australia (Elix 2007) and North America (Lendemer \& Lumbsch 2008) and it is locally common, for instance, in Costa Rica (unpublished, e.g., specimens Aptroot 60835, 60836, 60840 in the Herbarium of the National Biodiversity Institute, in Heredia, Costa Rica [code, INB] and the Herbarium of the Advice bureau for Bryology and Lichenology, in Soest, the Netherlands [code, ABL]). Recently, a third species with identical medullary chemistry (alectoronic acid) was described in the same species complex, viz. the sorediate Protoparmelia capitata Lendemer \& Lumbsch recorded for North America (Lendemer \& Lumbsch 2008).

The Serra da Jiboia mountain range of Brazil is in a transitional area between Atlantic Forest and caatinga (shrublands) vegetation, with a maximum elevation of $800 \mathrm{~m}$. This fragment of Atlantic Forest is located within the municipality of Santa Terezinha, Bahia, NE Brazil, near the border with the municipality of Castro Alves, both municipalities being in the state of Bahia, in northeastern Brazil. This area can be considered a rain-forest enclave surrounded by caatinga and belongs to a disjunct set of mountains that extend from the southern coast of the state toward the north and northwest, stretching into the Baia de Todos os Santos region (Queiroz et al. 1996).

\footnotetext{
${ }^{1}$ Advice bureau for Bryology and Lichenology Herbarium, Soest, The Netherlands

${ }^{2}$ Universidade Federal de Sergipe, Departamento de Biociências, Itabaiana, Sergipe, Brazil

${ }^{3}$ Author for correspondence: mscaceres@hotmail.com
} 
During a recent floristic survey of corticolous crustose lichens in fragments of the Atlantic Forest and caatinga in the state of Bahia, a large number of (mostly crustose) lichen species were found, several of them apparently new to science. One of the surveyed fragments was the Serra da Jiboia, in Santa Teresinha. Here, P. capitata was found to be quite abundant. The species is easily identified by its brown pigmentation, the huge hemispherical soralia and the presence of alectoronic acid in the medulla, which glows bright green under UV light.

\section{Material and methods}

Identification work was carried out in the Lichenology Laboratory of the Federal University of Sergipe, located in the city of Itabaiana, in the state of Sergipe, also in northeastern Brazil. Samples were examined with a stereomicroscope (EZ4; Leica Microsystems, Wetzlar, Germany) and a compound microscope (DM500; Leica Microsystems). Additional analyses were conducted at the Advice bureau for Bryology and Lichenology, in Soest, the Netherlands, also with a stereomicroscope (SZX7; Olympus America Inc., Center Valley, PA, USA) and a compound microscope (BX50; Olympus Optical, Tokyo, Japan) with interference contrast, connected to a digital camera (Coolpix; Nikon USA, Melville, NY, USA). The specimens analyzed during this study are preserved in the Herbarium of the Federal University of Sergipe Biosciences Department (code, ISE).

Protoparmelia capitata Lendemer \& Lumbsch, Lichenologist 40: 332. 2008.

Thallus covering extensive areas of bark, crustose, ca. $0.1 \mathrm{~mm}$ thick, very pale brown, corticate, a bit glossy, divided into more or less rectangular areoles $0.2-0.3 \mathrm{~mm}$ in diameter, surrounded by a ca. $0.3 \mathrm{~mm}$-wide dark brown prothallus line. Soralia covering most of the thallus, hemispherical, mostly $0.6-1.5 \mathrm{~mm}$ in diameter, initially of the same color as the thallus, but thereafter showing white medullae. Soredia granular, somewhat glossy, the same color as the thallus, characteristically present only on the sides of the soralia. Apothecia unknown from Brazil but known from North America (see description in Lendemer \& Lumbsch 2008).

\section{Chemistry}

Cortex with insoluble brown pigment. Medulla under $\mathrm{UV}+$ (bright green), $\mathrm{KC}+$ (pink), $\mathrm{K}-, \mathrm{P}-$ and $\mathrm{C}-$, with alectoronic acid (thin layer chromatography).

\section{Distribution}

Known from North America (Alabama, Florida and Georgia; Lendemer \& Lumbsch 2008) and now Brazil (Bahia). As far as is known at the moment, the three species of this species triplet have a different world distribution: P. pulchra is known only from Australasia; P. capitata is known from the American continent; and P. isidiata is pantropical.

\section{Discussion}

This species is easily confused with those of the sorediate genus Pertusaria (Pertusariaceae), from which it differs by having somewhat glossy, brownish soredia and medullary alectoronic acid, which is easily detected under UV light. Sorediate Pertusaria species invariably contain other medullary substances (xanthones, orcinol depsides, depsones, $\beta$-orcinol depsidones and depsides), which generally cause other reactions with spot tests or under UV light. The species that come closest in reaction are those with hypoprotocetraric acid, which also reacts strongly with UV light but glows white not green. This substance occurs in the common species Pertusaria subventosa Malme (Archer 1997), although that species often contains additional substances (which cause other reactions), such as lichexanthone (UV+ yellow). Other tropical corticolous crustose sorediate species (e.g., those in the genera Amandinea, Haematomma, Lecanora, Malmidea, Megalospora, Myeloconis, Myriotrema, Ocellularia, Rinodina) never contain alectoronic acid or other substances with similar reactions.

Specimens observed - BRAZIL. Bahia, Santa Teresinha, Serra da Jiboia, on bark of tree, elevation ca. $700 \mathrm{~m}$, 23 Sep 2010, M.Cáceres 7895, 7935, 7946, 7951 (all at ISE).

Including the species newly reported here, five species of the genus Protoparmelia are known from South America (Kalb 1984; Aptroot 2002; Cáceres 2007). They can be keyed out as follows:

\section{Key to Protoparmelia species in South America}

1a. Thallus with soredia or isidia; apothecia not known from South American specimens ................................................. 2

1b. Thallus without soredia or isidia, always with apothecia ........................................................................................ 3

2a. Thallus with soredia. Brazil, corticolous ........................................................ P. capitata Lendemer \& Lumbsch (Fig. 1A)

2b. Thallus with isidia. Brazil and Costa Rica, corticolous ....................... P. isidiata Diederich, Aptroot \& Sérus. (Fig. 1B)

3a. Ascospores numbering ca. 50 per ascus. Brazil, Colombia and Costa Rica, corticolous .... P. multifera (Nyl.) Kantvilas, Papong \& Lumbsch [syn. Lecanora multifera Nyl., Maronea multifera (Nyl.) Vain., Maronina multifera (Nyl.) Hafellner \& R.W. Rogers] (Fig. 1C)

3b. Ascospores numbering 6-8 per ascus 
4a. Thallus fissured, on rock. Brazil, Chile, Argentina, saxicolous

[syn. Lichen badius Hoffm., Lecanora badia (Hoffm) Ach.]

4b. Thallus smooth, on bark and cactus spines. Paraguay, corticolous

[as "badiola", syn. Lecanora dadiola Müll. Arg.]
P. badia (Hoffm.) Hafellner

P. dadiola (Müll. Arg.) Kalb
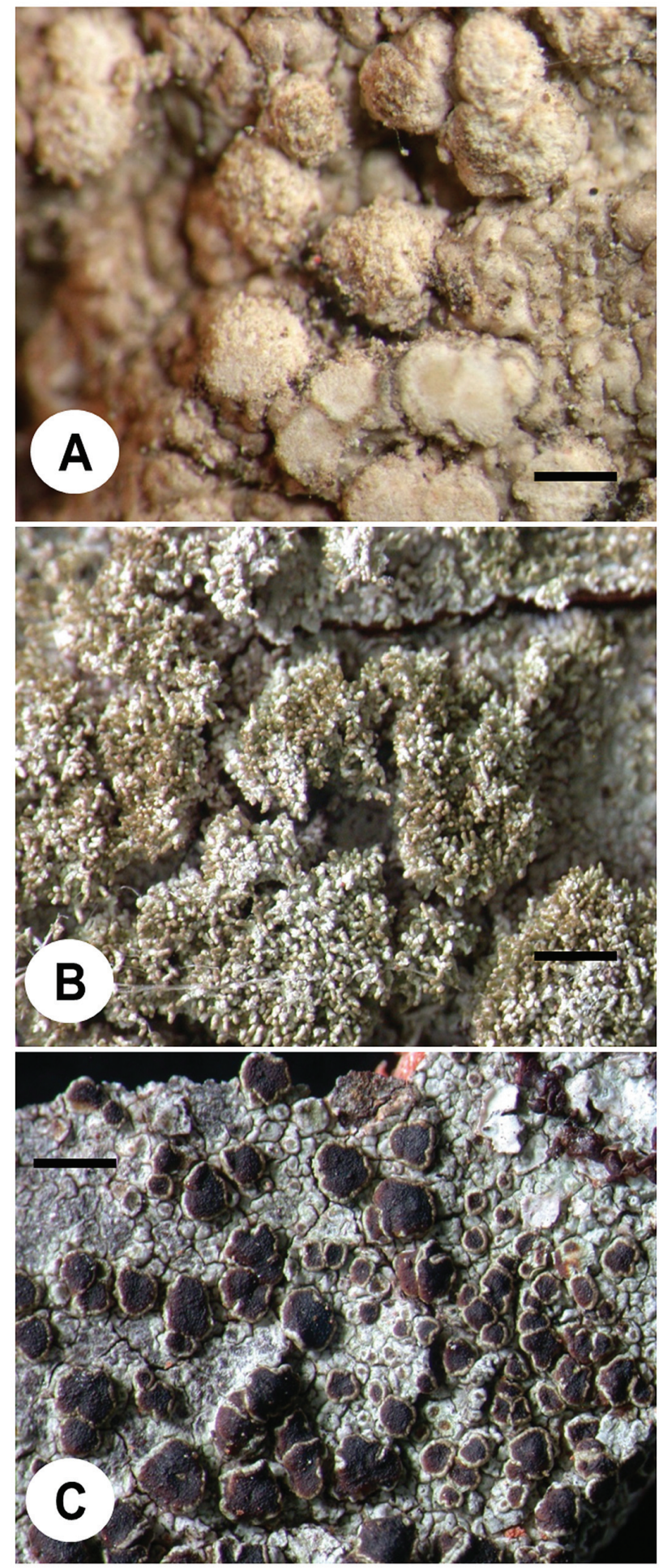

Figure 1. A) Protoparmelia capitata (Brazil, M.Cáceres 7895, ISE). B) Protoparmelia isidiata (Brazil, A. Aptroot 13673, BOTU, ABL). C) Protoparmelia multifera (Brazil, A. Aptroot 13667, BOTU, ABL). Scale $=1 \mathrm{~mm}$. 


\section{Acknowledgments}

This study received financial support from the Brazilian Conselho Nacional de Desenvolvimento Científico e Tecnológico (CNPq, National Council for Scientific and Technological Development; Research Grant no. 501633/2009-0 [to MESC] and PPBio/Semiárido Program Fieldwork Grant no. 558317/2009-0), as well as from the Stichting Hugo de Vries-Fonds (Hugo de Vries Foundation; travel grant to AA).

\section{References}

Aptroot, A. 2002. New and interesting lichens and lichenicolous fungi in Brazil. Fungal diversity 9: 15-45.

Aptroot, A.; Diederich, P.; Sérusiaux, E. \& Sipman, H.J.M. 1997. Lichens and lichenicolous fungi from New Guinea. Bibliotheca Lichenologica 64: 1-220.

Archer, A.W. 1997. The lichen genus Pertusaria in Australia. Bibliotheca Lichenologica 69: 1-249.

Arup, U.; Ekman, S.; Grube, M.; Mattsson, J.-E. \& Wedin, M. 2007. The sister group relation of Parmeliaceae (Lecanorales, Ascomycota). Mycologia 99: 42-49

Boom, P.P.G. van den; Sipman, H.J.M.; Elix, J.A. 2007: Protoparmelia. Pp. 392-393. In: III Nash, T.H.; Gries, C. \& Bungartz, F. (Eds). Lichen Flora of the Greater Sonoran Desert Region. Vol. 3. Lichens Unlimited, Tempe, Arizona State University.

Brodo, I.M. \& Aptroot, A. 2005. Corticolous species of Protoparmelia (lichenized Ascomycotina) in North America. Canadian Journal of Botany 83: 1075-1081.
Cáceres, M.E.S. 2007. Corticolous crustose and microfoliose lichens of northeastern Brazil. Libri Botanici 22: 1-168.

Elix, J.A. 2007. Additional lichen reports from Australia 64. Australasian Lichenology 61: 8-15.

Henssen, A. 1995. Apothecial structure and development in Protoparmelia badia (Parmeliaceae s. lat.). Pp. 55-62. In: Daniëls, F.J.A.; Schulz, M. \& Peine, J. (Eds.). Flechten Follmann. Contributions to lichenology in honour of Gerhard Follmann.

Kalb, K. 1984. Lichenes Neotropici ausgegeben von Klaus Kalb. Fascikle VIII (Nos 301-350). Neumarkt/OPf.

Lendemer, J.C. \& Lumbsch, H.T. 2008. Protoparmelia capitata sp. nov., and P. isidiata Diederich, Aptroot \& Sérus., two species of Protoparmelia (Lecanorales, Ascomycota) from south-eastern North America. Lichenologist 40: 329-336.

Papong, K.; Kantvilas, G. \& Lumbsch, H.T. 2011. Morphological and molecular evidence places Maronina into synonymy with Protoparmelia (Ascomycota: Lecanorales). Lichenologist 43: 561-567.

Poelt, J. \& Grube, M. 1992. Beiträge zur Kenntnis der Flechtenflora des Himalaya. V. Die Gattung Protoparmelia Choisy. Nova Hedwigia 55: 381-395.

Poelt, J. \& Leuckert, C. 1991. Der Formenkreis von Protoparmelia atriseda (Lichenes, Lecanoraceae) in Europa. Nova Hedwigia 52: 39-64.

Queiroz, L. P.; Sena, T. S. N. \& Costa, M. J. S. L. 1996. Flora vascular da Serra da Jiboia, Santa Terezinha - Bahia. I: o campo rupestre. Sitientibus 15: $27-40$

Ryan, B.D.; Nash, T.H.III \& Hafellner, J. 2004. Protoparmelia. Pp. 425-430. In: III Nash, T.H.; Ryan, B.D.; Diederich, P.; Gries, C. \& Bungartz, F. (Eds.). Lichen Flora of the Greater Sonoran Desert Region. Vol. 2. Lichens Unlimited, Arizona State University, Tempe, Arizona. 